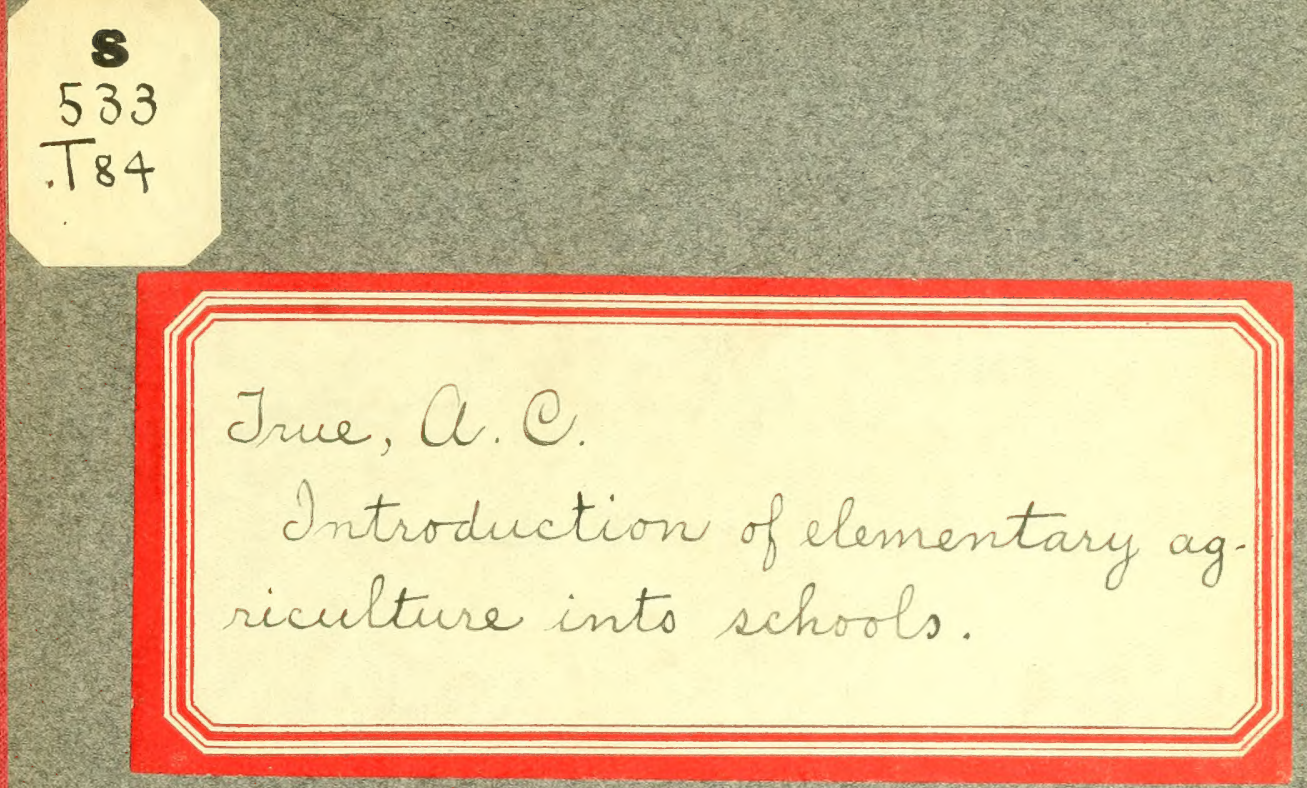




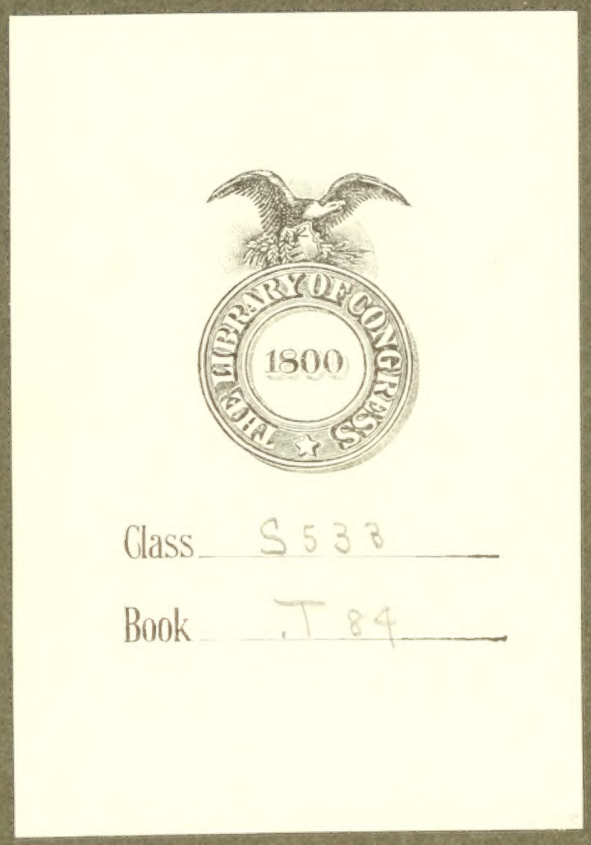

Class 5538

Book

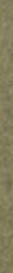




\section{INTRODUCTION OF ELEMENTARY AGRICULTURE INTO SCHOOLS.}

A. C. TRUE,

Director of the Office of Erperiment Stations.

[Reprint From Yearbook of Departuent of Airiculture for 1906.]

$4550-07$ 


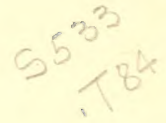

\section{CONTENTS.}

Interest amono farmers' organizations - Page.

Attitude of school officers and teachers ............................ 152

Progress in legislation ........................................ 155

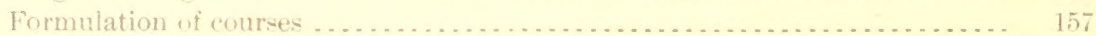

Preparation of text-books and manuals .......................... 158

Provision for training teachers .................................... 159

(Mrganization of agricultural schools ............................. 160

Number of pupils studying agriculture ......................... 161

How farmers may help the sehools ............................... 162 


\title{
INTRODUCTION OF ELEMENTARY AGRICULTURE INTO SCHOOLS.
}

\author{
By A. C. TruE, \\ Director of the Office of Experiment Stations.
}

The teaching of improved methods of agriculture to the masses of our agricultural youth has recently been advocated by the President of the United States, the Secretary of Agriculture, a former United States Commissioner of Labor who is now the president of a Massachusetts college, the president of one of our greatest railroads, the president of the University of Virginia, the superintendent of schools of New York City, acting as president of the National Educational Association, and by such bodies as the National Educational Association, the National Grange, and the National Irrigation Congress. This may fairly be taken as a sure indication that the discussion of this subject has become very widespread, and that public opinion is becoming erystallized in favor of using the schools for the dissemination of agricultural knowledge. After a long period of comparative neglect of agricultural interests by the leaders of thought and action in this country, a great awakening to the tremendous issues which are involved in the permanent prosperity of our agriculture and in the maintenance of a high level of intelligence among our agricultural people has come, and happily the minds of our most influential men are turning more and more to the public schools as the fittest and best centers from which to spread a knowledge of the principles of agriculture and in which to inculcate a love of country life and an appreciation of the dignity of agricultural pursuits. Sentiments favorable to agriculture are no longer expressed by our public men simply as a compliment to our farmers. It is rather a new and serious sense of the real importance of the farmer to the commonwealth, and a fear of the perils into which the crowding of our population in great cities and the neglect to maintain the fertility of our soil are sure to bring us, that are leading thoughtful men of all classes to pay earnest attention to the educational needs of our rural population. This means a great step in advance on this subject. It is now possible to secure a fair hearing of the claims of agriculture to a place in our public schools and a thorough testing of plans for the teaching of this subject in a wide and effective way. It becomes important, therefore, to look more closely at the methods which are being pursued to acquaint our 
farmers, educators, and legislators with the needs of the rural schools in different parts of our country and to make definite suggestions for their improvement.

Under the authority of Congress and the Secretary of Agriculture the Office of Experiment Stations has been collating information from various sources regarding the progress of this movement, and the present summary is presented to show in brief the results of this investigation.

\section{INTEREST AMONG FARMERS' ORGANIZATIONS.}

Our investigation shows that in the farmers organizations throughout the country, which as a rule comprise our more intelligent and progressive farmers, the introduction of agricultural instruction into the schools is being actively discussed and warmly approved. Local organizations are passing this question up to the State organizations, and these in turn are sending it on to the National oranizations. Committees on legislation are being appointed, and there are many cvidences of an earnest and persistent effort to secure definite results.

Not content to wait for the formulation of definite courses of instruction in agriculture for the rural schools and the training of teachers in this subject, there is in many places an effort to do something tangible to arouse the interest of farmers boys in the study of agriculture. Throurh the ageney of farmers organizations cooperating with the State agricultural colleges and State and county departments of education, boys' agricultural clubs have been organized, largely in connection with the schools, in Georgia, Illinois, Indiana, Iowa, Kansas, Nebraska, Ohio, Texas, and probably other States. The members of these clubs have regular institute meetings and lecture courses, go on excursions to educational institutions and large farms, conduct variety tests with corn, cotton, sugar beets, and other crops, and exhibit their products at school, county, and State fairs.

The agricultural press is devoting a larger space than ever before to the discussion of educational topies, and wherever an attompt is made to establish the teaching of agriculture in the schools it is widely and fully advertised. Entire numbers of some papers are given up to the presentation of various phases of agricultural education.

\section{ATTITUDE OF SCHOOL OFFICERS AND TEACHERS.}

A remarkable change has taken place in the attitude of school officers and teachers regarding nature study and elementary agriculture as school subjects. A few years ago it was unusual to find any subject relating to agriculture in public schools in the programmes of teachers meetings. Now scarcely an educational meeting of importance is held anywhere in the United States without at least one paper 
on some phase of this subject, and in many cases whole sessions are devoted to the disenssion of various topies relating to it, from nature study and sehool gardening to the more formal courses in arieulture. A few examples will serve to show how widespread is this interest.

At the sixty-seventh annual convention of the American Institute of Instruction at New Haven, Conn., in July, 1906, which is largely attended by school officers and teachers from different parts of New England, the teaching of elementary agriculture was largely discussed in the department of rursl education, formal papers on this subject being presented by the superintendent of education of Vermont and the professor of agriculture of the Massachusetts Agricultural College.

New England has also been aroused to a serious and thorough discussion of this matter by the report of a commission on industrial and technical education presented to the legislature of Massachusetts in April, 1906. The chairman of this commission was Hon. Carroll D. Wright, for many years United States Commissioner of Labor and now president of Clark University at Worcester, Mass. This commission was appointed by the governor of Massachusetts in accordance with an act of the legislature, and spent nearly a year in a study of the relation of children to our industries and the condition of industrial education at home and abroad. The commission found that "there is a widespread interest in the general subject of industrial education, or special training for vocations," but that our people generally, and even those who are most interested in the subject, have no definite ideas as to its proper scope or method. "Compared with the opportunities afforded in Europe for acquiring knowledge and skill in productive industry, the work now being done in Massachusetts is strikingly and painfully inadequate," and while in this country "the general public has been strangely blind to the narrowness of the public school education," in Europe there is "the universal recognition of the necessity of special education for every form of industrial life." Among their conclusions were the following:

The State needs a wider diffusion of industrial intelligence as a foundation for the highest technical success, and this can only be acquired in connection with the general system of education into which it should enter as an integral part from the beginning. The latest philosophy of education reenforces the demands of productive industry by showing that that which fits a child best for his place in the world as a producer tends to his own highest development physically, intellectually, and morally.

There seem to be two lines in which industrial education may be developed-(1) through the existing public school system, and (2) through independent industrial schools. In regard to the former the commission recommends that cities and towns so modify the work in the elementary schools as to include for boys and girls instruction and practice in the elements of productive industry, including agriculture and the mechanic and domestic arts, and that this instruction be of such a character as to secure from it the highest cultural as well as the highest industrial value; and that the work in the high schools be modified so that the instruction in mathematics, the sciences, and drawing shall show the application and use of these subjects in industrial 
life, with special reference to local industries, so that the students may see that these subjects are not designed primarily and solely for academic purposes, but that they may be utilized for the purposes of practical life-that is, algebra and geometry should be so taught in the public schools as to show their relations to construction; botany to horticulture and agriculture; chemistry to agriculture, manufactures, and domestic sciences, and drawing to every form of industry.

The commission would also recommend that all towns and cities provide, by new elective industrial courses in high schools, instruction in the principles of agriculture and the domestic and mechanic arts.

This commission has been continued, and Prof. Paul Hanus, professor of the history and art of teaching in Harvard University, has been appointed chairman. Professor Hanus is thoroughly alive to the need of industrial education, believing that "the education demanded by democratic society in modern times must be a preparation for active life," and that "the only real preparation for life's duties, opportunities, and privileges is participation in them, so far as they can be rendered intelligible, interesting, and accessible to children and youth of school age." This being so, he favors "liberal provision for elementary training in agriculture, industrial and commercial pursuits, in addition to general manual training, at the upper end of the grammar school and also at the upper end of the high school."

In New York, at the annual meeting of the State Association of School Commissioners and Superintendents, held at Cornell University, in October, 1906, the best means of adapting rural schools to their enviromment was discussed, and it was generally agreed that agriculture should be taught as a part of the general scheme of pedagogy, of which it should be the basic factor.

In Indiana the county superintendents in twelve counties have organized clubs for the study of crops, and the Association of County Superintendents has asked Purdue University to organize a training school for teachers in agriculture and nature study.

The State Teachers' Association of Michigan at its meeting in 1905 adopted resolutions favoring the teaching of agriculture in the public schools.

In Missouri the State superintendent made the following statement in his report for 1904 :

Fifteen years ago I urged at county teachers' associations and granges that the elements of agriculture be taught in public schools. Since then sentiment has grown until there is a great demand for it. For five years the law has recognized it by making it one of a group of subjects from which applicants must select to be examined for firstgrade certificate or State certificate. Four years ago State normal schools established departments of agriculture and nature study. There are now many teachers in the State prepared to teach elementary agriculture.

In 1905 the Missouri State Teachers' Association asked that agriculture be made a requirement for any grade of teachers' certificate.

In California, at a joint meeting of the State 'Teachers' Association and the State Farmer' Institute, held at the University of California 
in December, 1905, and attended by some 7,000 persons, the subject of agricultural education was discussed from various points of view, and as a result of this meeting a committee was organized to promote the interests of such education in the public schools of the State.

At a conference for education in the South, held at I.uexington, Ky., in May, 1906, and attended by leading educators from a number of States, much attention was given to the claims of agriculture to a place in the school curriculum.

At the meeting of the Virginia State Teachers' Association and affiliated organizations in November, 1906, the teaching of agriculture in the public schools was widely and thoroughly discussed, and President Alderman, of the University of Virginia, in the closing address of that great meeting, declared that among the things which should be considered as settled in the campaign for a better school system now being actively carried on in that State was that agriculture in some form should be generally taught in the schools,

At the annual convention of the National Educational Association, held at Asbury Park, N. J., in July, 1905, elementary agricultural instruction was a prominent subject of discussion, and such instruction was favored in the annual address of the president, Dr. William H. Maxwell, superintendent of schools of New York City, delivered to thousands of teachers at the opening session. The committee on industrial education in schools for rural communities, appointed two years before, brought in an elaborate report, in which it maintained "that the rural schools, which train nearly one-half of the school population of this country, should recognize the fact that the major portion of their pupils will continue to live upon the farm, and should provide specific, definite technical training for them for the activities of farm life. It adduced strong arguments in support of this position and emphasized the educational value as well as the practical utility of courses of study framed with this end in view. The committee favored the consolidation of rural schools in order that teachers specially fitted for this work might be secured and the instruction made more efficient. It also advocated the establishment of high schools to meet the special needs of the rural population for secondary education directly related to agricultural practice.'

\section{PROGRESS IN LEGISLATION.}

Steady progress is being made in securing legislation favorable to the teaching of agriculture in public schools. The laws of over 30 States now permit or require such instruction. Among the States which require the teaching of agriculture in all elementary schools are Alabama, Georgia, Louisiana, Maine, Maryland, Mississippi, North Carolina, South Carolina, South Dakota, and Wisconsin. Legislation on this subject is commonly accompanied with provisions making 
agriculture one of the subjects on which teachers may or must be examined. In Nebraska, for cxample, candidates for first and second grade county certificates must pass an examination in the elements of agriculture. In Wisconsin, since 1901, teachers have been required to pass an examination in elementary agriculture in order to secure any grade of teachers' certificate. In New Hampshire teachers in secondary schools are required to have training in agriculture. In Virginia teachers securing first-grade certificates must pass an examination on either physical geography, elementary physics, or elementary agriculture. In Alabama, Georgia, Mississippi, Missouri, North Carolina, and South Dakota all teachers must pass examination on this subject. In New York the new syllabus for elementary schools contains nature study and agriculture, and teachers in training classes are required to cover all subjects in the syllabus. In Ohio the Teachers' Reading Circle requires the study of one text-book on elementary agriculture each year. The laws are also beginning to recognize the fact that definite provision should be made for the training of teachers along agricultural lines. Thus a recent act in Michigan, which enables counties to maintain normal training classes with State aid, requires the teaching of agriculture to such classes. In Massachusetts the legislature appropriated $\$ 5,000$ for normal work at the State Agricultural College as one result of the report of the commission on industrial education above referred to.

It is also being seen that the high schools are very largely the institutions in which the teachers of the rural schools receive their most advanced training, and this fact is now making it easier to secure legislation for high-school instruction in agriculture. Already under State laws there are agricultural high schools in Alabama, California, Minnesota, and Wisconsin. In 1905 the Minnesota legislature passed an act providing for local option in the establishment and maintenance of county schools of agriculture and domestic economy, limiting to $\$ 20,000$ the amount which any county may appropriate for this purpose in one year. Two or more counties may unite to establish such a school. Each school must have connected with it a tract of land suitable for experiments and demonstrations of not less than 10 acres.

At the session of 1906 the Georgia legislature passed an act establishing 11 agricultural high schools, as branches of the State College of Agriculture. These schools will each receive from the State about $\$ 6,000$ a year, derived from the inspection fees collected by the State department of agriculture, but each community in which such a school is located must furnish not less than 200 acres of land and the necessary equipment. The people are responding enthusiastically to this requirement, and about $\$ 800,000$ in land and money has been offered for the equipment of these schools. 
In New Hampshire, beginning with 1906, high schools and academies may be approved by the State superintendent of education if they are prepared to teach agriculture.

Recent legislation in Virginia provides for the establishment of public high schools under the authority of the State superintendent of education. Arrangements are being made to open about 150 such schools, and it is intended to make instruction in agriculture a feature of the course in such of these schools as are located in the rural districts.

\section{FORN'UAATION OF' COURSES,}

One of the objections often made to the introduction of agriculture into our schools is that the teacher's do not know what should be taught under this head. This may have been a valid excuse in the past, but to-day is no longer so. While there is still much difference of opinion as to details, the general scheme of instruction has been pretty well worked out. For example, the Office of Experiment Stations has published an outline plan of a course in nature study and elementary agriculture for rural schools. 'This was prepared by a committee of the Association of American Agricultural Colleges and Experiment Stations, and therefore represents broadly the views of educators in different parts of the country on this subject. In this publication, ${ }^{a}$ which may be obtained on application to this Department, it is suggested that during the first six year's of the child's attendance at school he should be led to make observations of the plants and animals on the farm and in the fields and woods, together with simple studies of soils, weather conditions, and other natural objects and phenomena. A more formal study of climate, soils, fertilizers, farm crops, fruits, domestic animals, dairying, farm buildings and machinery, marketing, and farm accounts is outlined for the seventh and eighth school years. The committee has followed this with a series of simple exercises and demonstrations on some of the elementary principles of agriculture. These have recently been published as a circular of the Office of Experiment Stations.

In Missouri a course in agriculture for the public schools was prepared several years ago by the State superintendent of sehools. 'This has since been superseded by a more nearly complete presentation of this subject in a bulletin prepared by the State superintendent and published by the State board of agriculture. This bulletin advocates presenting the subject of agriculture "(1) by experiments at home and in the field, (2) by studying facts as given in texts and bulletins, and (3) by school gardens connected with sehool grounds." Numerous experiments and observations are suggested throughout the bulletin.

a Office of Experiment Stations ('ireular 60, The Teaching of Agrieulture in the Rural common sichools 
In Illinois a somewhat detailed course has been prepared by the dean of the College of Agriculture. This course is arranged by months, and gives suggestions for a large number of experiments and observations bearing on all the divisions of agriculture. Considerable reading along agricultural lines is suggested, as well as drawing, composition, and other work intended to correlate agriculture with other school work. This Illinois course has not only been used in that State, but has also been adopted by several other States and published in the reports of their State superintendents of education.

In Mimesota a bulletin prepared by Prof. W. M. Hays, then professor of agriculture of the College of Agriculture and now Assistant Secretary of Agriculture, has been widely used in the schools of that and other States. This bullet in contains a large number of practical and illustrative exercises for use in comection with elementary instruction in agriculture.

In Wisconsin the State superintendent of public instruction, in 1906 , prepared an outline for instruction in the elements of agriculture for the use of teachers in common schools. In this outline it is recommended that agriculture be taught in the last half of the eighth rear, and that nature study be given in all grades through general exercises and in connect ion with language exereises, geography, reading, and history. The outline is divided into three parts, (1) agriculture, including the soil, water and the soil, tilling the soil, soil enrichment, the plant, the leguminous plants, plant enemies, rotation of crops, selection of seed, the farm garden, weeds, and home and school gardens; (2) farm animals, including care and feeding, type forms, and lium economics, and (3) farm poultry.

Outlines of courses, sample lessons, and other helps for teachers have also been published by the State departments of education in Georgia, Indiana, Maine, Nichigan, Missouri, Nebraska, North Carolina, New Itampshire, New York, and probably in other States.

The New York State department of education has published a syllabus of a course in agriculture for high schools, and this will be followed by a detailed series of lessons and laboratory and field exereises.

PREPARATION (OF TEXT-BOOKS AND MANUALS.

The demand for text-books, manuals, and reference books on agrieulture adapted to school use is steadily growing. The agricultural experts comected with our agricultural colleges and experiment stations are thus encouraged to prepare such books, and publishers are now act ive in seeking for books of this character. The number of bulletins useful to teachers and students which are issued by the United States Department of Agriculture and the State experiment stations has greatly increased in recent years, and the demand for these from educational institutions is now large. Among elementary text-books 
which are already used more or less extensively in schools are Burkett, Stevens and Hill's Agriculture for Begimners; Goff and Mayne's First Principles of Agriculture; Bailey's Principles of Agriculture; Goodrich's First Book of Farming; Brooks's Agriculture; Jackson and Daugherty's Agriculture through the Laboratory and School Garden; Shepperd and McDowell's Elements of Agriculture (prepared especially for North Dakota schools), and Hatch and Haselwood's Elementary Agriculture with Practical Arithmetic. 'The last mentioned is an interesting attempt to correlate instruction in agriculture with that in arithmetic by connecting with the several lessons in agriculture a number of practical arithmetical problems directly relating to the farm. For the high-school library and the teachers' use we have such advanced manuals as Hunt's Cereals in Amerien; Smith's Profitable Stock Feeding; Henry's Feeds and Feeding; Jordan's Feeding of Animals; King's Soil, Irrigation and Drainage, and Physies of Agriculture; Decker's Dairying; Snyder's Chemistry of Plant and Animal Life; Mead's Irrigation Institutions; 'Taylor's Agricultural Economies, and others. For general reference books we have the new International Encyclopedia; Bailey's Eneyclopedia of Horticulture; Wilcox and Smith's Encyclopedia for Farmers; Bailey's Garden Craft and Rural Science Series; the Yearbooks of the United States Department of Agriculture, and others of similar character. The bulletins and books which the schools can easily secure contain many descriptions and illustrations of simple and inexpensive apparatus and other facilities which may be purchased or made by the teacher. There is no excuse for keeping agriculture out of the schools to-day because of a lack of suitable books or other aids to such instruction. Suggestions for the adaptation of country schoolhouses to this new work are now being made. At Cornell University a model schoolhouse is being erected, which, in addition to the usual recitation room, will have a large laboratory for nature study and elementary agriculture.

PROVISION FOR TRAINING TEACHERS.

Realizing that a vital point in the effective teaching of agriculture in our public schools is the training of teachers in this subject, the friends of this movement are now making active eftorts to establish agricultural courses for teachers in our colleges and normal schools. The agricultural colleges in a number of States have given instruction to considerable mumbers of teachers at summer schools. They ane now begimning to establish regular normal courses, provision for such work having recently been made at the colleges in Illinois, Mississippi, Massachusetts, Michigan, Missouri, and New York. The colleges in Ohio, Iowa, Illinois, New York, Mississippi, and Rhode Island also have so-called extension departments which are seeking to come into close 
touch with teachers as well as with country boys and girls, and thus promote the wider diflusion of agrientumal education. These colleges are also using their influence to tmm students in their regular courses to the career of abching. The agricultural high schools, whether attached to the agricultural colleges or independent of them, are also training feachers. Some of the normal schools in Alabama, Georgiat. Idaho, Illinols, Lowa, Califomia, Louisiana, Maine, Massachusetts, Michigan, Missouri, Montana, Nehraska, North Dakota, (Oklahoma, Texas, Vermont, Virginia, Washington, West Virginia, and Trisconsin are giving regular instruction in nature study and elementary agriculture.

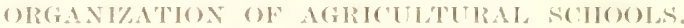

Meanwhile the establishment of courses in agriculture in secondary and primary schools is going on in diflerent parts of the combery. The agricaltural high schools organized in connece ion with the agrieultural collexes in Minnesotal, Vebraska, Oklahoma, Rhode Island, and Washington report an increased mumber of students, and are betterequipped than ever before. 'The National Farm School at Doylestown, Pa., has been reencrized by the state lecislature, which granted it an apperopriation of $\$ 12,000$, to be used for agrienltural instruetion. This school now receives more applieants for admission than it can aceonmodate, and is obliged to keep al wainge list. In Wisconsin the Dum (ounty school of Agriculture and Domest ie Eeonomy at Melominese has graduated three classes 21 boys and crirls in 1904, 19 in 190), and 16 in 1906. The California Polytechnic sehool, at san Luis ()bispo, has become firmly established and has a good expuipment and a considerable number of agrieultural students. The nine distriet agricultural schools in Alabama are steadily growing in popularity, and the eflicemer of their agricultural work has been much increased. The agrienltural course at the Moumt Hermon School, in Massachusetts, is beinge well maintained. In Misouri agrienlture is being taught in 200 high schools, in (Ohio in 30 , and in one or more sehools in Alabana, New Ilampshire, Pemnstrania, New Tork, Iowa, Kansas, Nebraska, Louisiana, Indiana, Maine, Idaho, Montana, North Dakota, Oklahoma, South (arolina, Temmessere, Texas, Utah, Virginia, Washington, and Wisconsin.

Agricultural high schools have recent ly been organized at Crookston, Minn., and Calvert, Md. At the latter a graduate of the Iowa Agricultural college has been elected principal, and a course of study elosely following the course recommended by the committee on instruction in agriculture of the Association of Ameriean Agrieultural Colleges and bxperiment Stations ${ }^{a}$ has been adopted, and the 


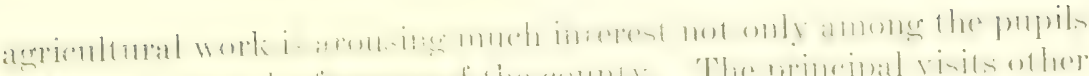

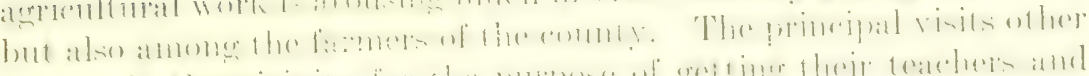

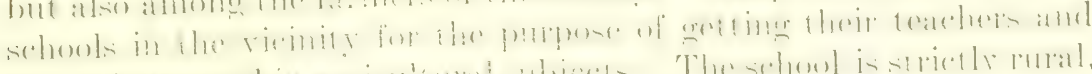

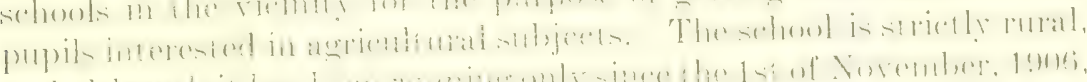

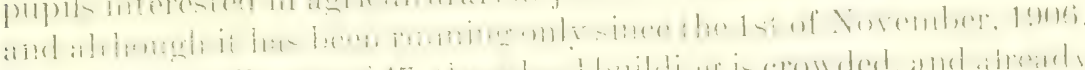

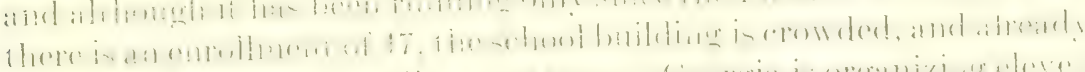

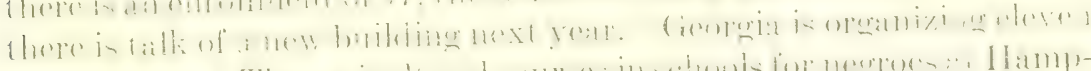

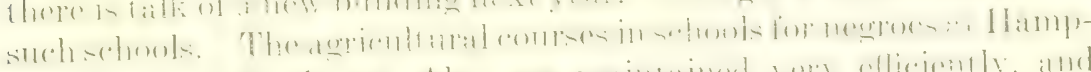

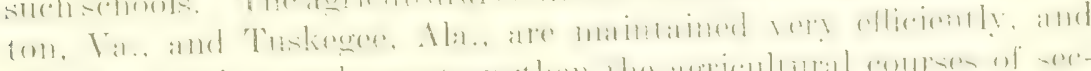

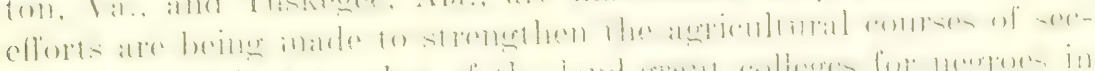

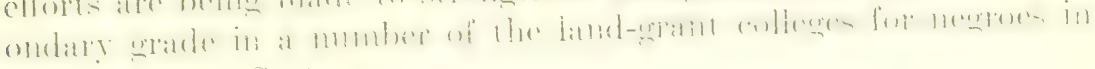
other Southern States.

In Ohio it is reported that elementary acrienlture is taught in

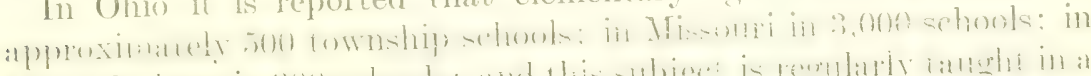

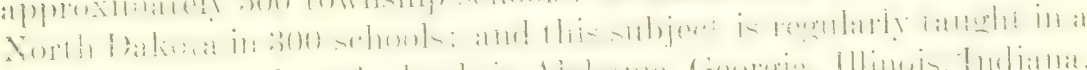

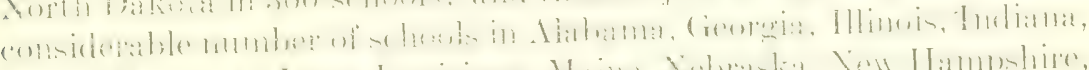

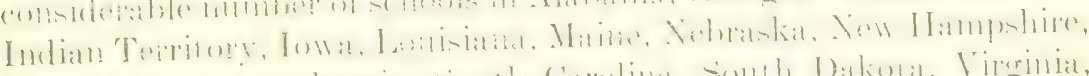

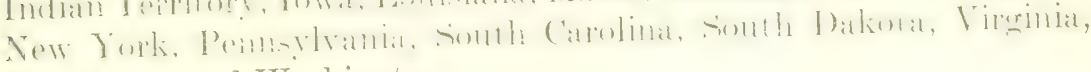
Wisconsin, and Washington.

NEMBER OF PUPILE STUDIING AGRICULTURE,

Reliable statistics of the number of pupils studying anculture in

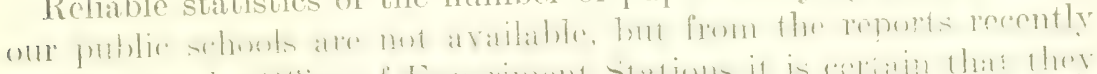

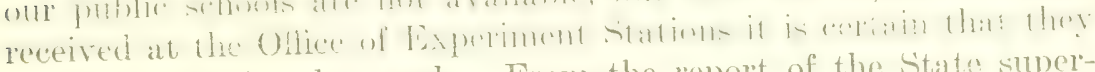
are numbered by thousands. From the report of the sitate super-

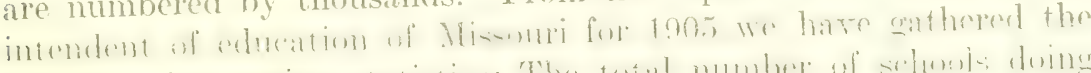

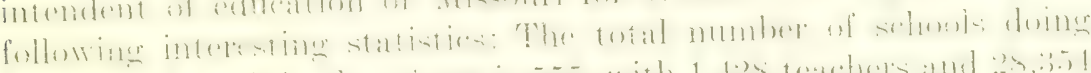

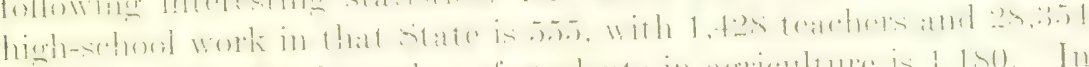

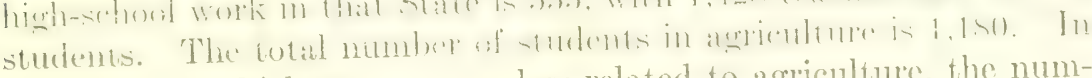
the sciences, which are more or less related to agrienlture, the numbers are as follows: Botany, 2, 742; zoology, 1,305; chemistry, 1, 492;

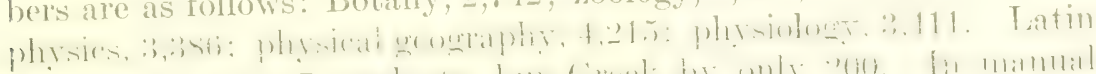

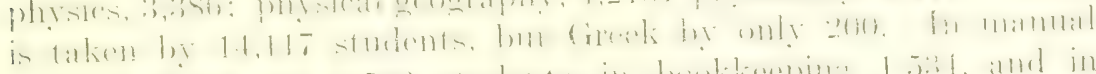

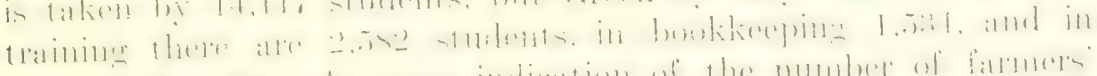

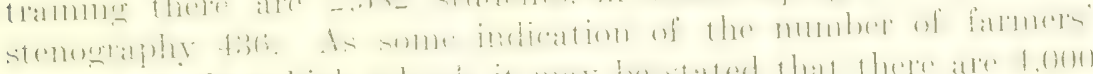

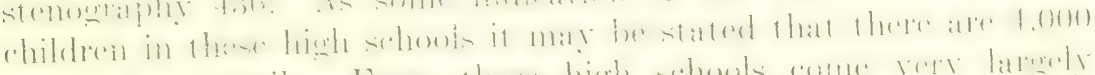

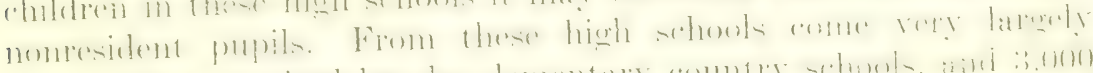

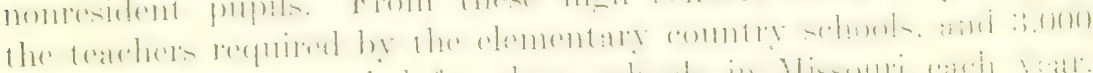

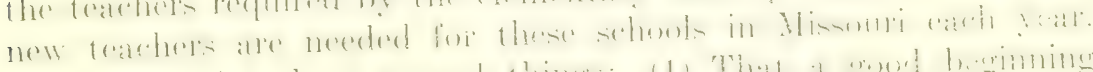

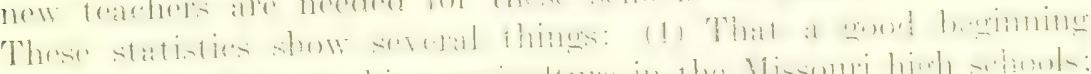

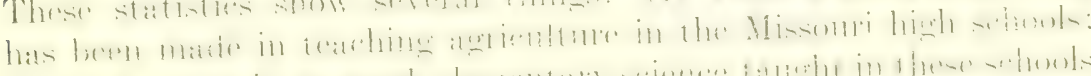

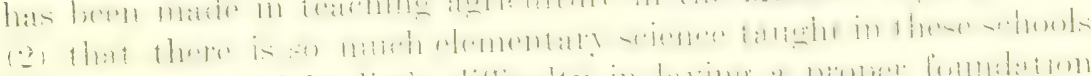

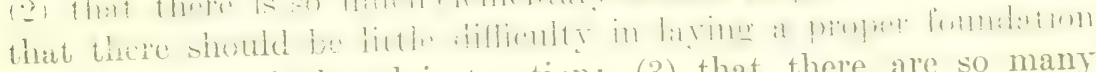
for eflective agricultural instruction; (3) that there are so many 
farmers' ehildren in these sehools that with proper courses of instruction the high schools of Missouri may easily become powerful agencies for sending back to the farms young people thoroughly alive to the advantages of country life and the requirements of a progressive agriculture; (4) that it is vital to the advancement of the best interests of the elementary rural schools that the atmosphere and instruction of schools should be favorable to agriculture, for to these high schools the country school must largely look for teacher's.

\section{HOW HARMERS MAY HELP THE SCHOOLS.}

Having now reviewed the progress which has been made in recent years in opening the way for the teaching of agrieulture in our public schools, it may be well to give brief attention to some of the ways in which the farmers themselves may further promote the improvement of the rural schools in this and other respects. Our acricultural communities have never been so prosperous as to-day. And there is every reason to believe that with intelligent management of the land and sound judgment in the marketing of the products this prosperity may be permanently maintained. The farmers now have the means to improve not only their lands and buildings, but also their general social conditions. The experience of the past century has shown that a thorough and effective school system in which the curriculum recognizes the industrial, intellectual, and social needs of the community is a most influential factor in promoting material wealth, as well as a broad and satisfactory life. Our farmers will be wise, therefore, if they use a portion of their increased means to strengthen and improve the rural schools. Some have feared that agricultural prosperity would lead to a neglect of education in our rural communities. But the indications are that this is not to be so. Our agricultural colleges and schools report both an increase in the number of students and an improvement in their quality. It appears that with the improvement of agricultural conditions there is a renewed interest in farming as a business, and farm boys of strong mental caliber and active ambition are seeking in larger numbers to prepare themselves in the best way for a life on the farm.

There is aiso widespread recognition of the fact that our present agricultural prosperity rests on a different basis from that of prerious periods in our history. There have been times when multitudes of our farmers were prosperous because they had occupied large areas of virgin soil freely granted them by the Government or purchased at a very low price. To-day our agricultural prosperity has come partly from increased demand for farm products at home and abroad and partly from the more skillful use of the land and the growing of improved crops and animals. And the improvement of agricultural 
methods and products has been very largely the result of the work of the United States Department of Agriculture and the State experiment stations. Technical and scientific knowledge is, as never before, a requisite of the most successful farming. The schools can be made efficient aids to the acquirement of that knowledge which our farm youth must have in order to perpetuate and extend the prosperity which their fathers now enjoy. Therefore our intelligent farmers are seeking to improve the rural schools, and will do so more actively as they come more generally to understand the importance of such action.

Better-trained teachers, improved school houses and grounds, more apparatus and books, free transportation of pupils to consolidated schools, high schools made available to all country children, and the teaching of agriculture and home ecomonics will cost something, and if they are to be had they must be paid for. But unless all past experience is a false guide, this improved school system will be one of the most profitable investments ever made by a civilized community. And if our farmers are alert to their interests they will push these improvements along rapidiy, and they will not permit the entire expense to come out of the taxable farm property. The villages and cities, whose prosperity rests on the farms, and the accumulated wealth of the State should contribute to the education of the rural people. This is already recognized in a number of our States as a wise and just principle. The nation has also recognized it by appropriating large sums for the higher agricultural education.

It can not be too strongly urged that the movement for the improvement of the rural schools, and in particular for the teaching of topics directly relating to agriculture and farm home life, should receive the active support of the masses of our farmers. And this support should be felt in our legislatures, boards of education, and local school management. This will require study of the present condition of our rural schools and careful consideration of their needs. As regards agricultural instruction there should be an understandirg of what the elementary and secondary schools may properly teach and the relation of such studies to those ordinarily pursued in our schools. For example, our farmers should conre to understand that it is not the ordinary practice of agriculture which can or should be taught in the public schools. It is rather the observation of the things in the natural world which the farmer has to deal with, the use of natural laws for the benefit of agriculture, the reasons why certain farm practices are beneficial and others injurious to the land that the school may teach. For example, in a dairy region the composition of milk, the causes of the souring of milk, and the ways of preventing this may be taught in school; in a potato-growing region, the nature and cause of potato blight, the reason why it is necessary to spray the vines before the disease appears; where the 
soils are deficient in nitrogen, the advantage of green manuring with leguminous plants and the reasons therefor; in an arid region, the use of the soil mulch and why it prevents the escape of soil moisture. And, above all, the farmer should see to it that the rural school-teacher is a friend of agriculture and loses no good opportunity to show his or her pupils the advantages and opportunities of country life.

The farmers can also do a great deal to promote the teaching of agriculture in the rural schools by encouraging the teachers to take up this subject and to prepare themselves to give instruction in it. The farmers are very largely the managers of rural schools and their children are the teachers in them. Merely by taking an active interest in the local schools, inviting the teachers and scholars to visit the farm, especially when there are unusually good crops and fine animals to be seen there, or sending specimens of products or injurious birds or insects to the school, the intelligent farmer may help to create a sentiment in favor of agricultural instruction there. Teachers, like other workers, will inevitably respond to an active demand for new things. As soon as it becomes generally understood that the farmers are bound to have agriculture taught in the schools, candidates for teachers' positions will get ready to teach it. With many of our educational leaders fully believing that subjects directly related to the life work of the pupils should be taught and a host of the intelligent farmers insisting that our future agricultural prosperity will largely depend on such teaching in the schools, a way will surely be found to bring this great reform to a successful issue. Meanwhile let us have great patience with even the most imperfect attempts on the part of our schools to work along this line. The whole matter of elementary and secondary instruction in agriculture is in an experimental stage. Many trials of courses, methods of teaching, books, apparatus, and other facilities must be made before plans fully adapted to the conditions of different agricultural regions can be matured. Intelligent and kindly criticism should be invited and utilized by all who are engaged in this work. In this way alone can the best progress be made.

What is now being done, with all its imperfections, is tremendously important. Principles of action are being determined. Every successful example of the effective teaching of agriculture, whether in a little country school or in the agricultural high school, is helping to indicate along what line the future growth of this movement must proceed. There is therefore much cause for congratulation that in so many different States and under such a variety of conditions honest and substantial efforts are being made to solve the problems of our rural schools and to test the usefulness of agricultural instruction as a means of improving country life and perpetuating agricultural prosperity. 


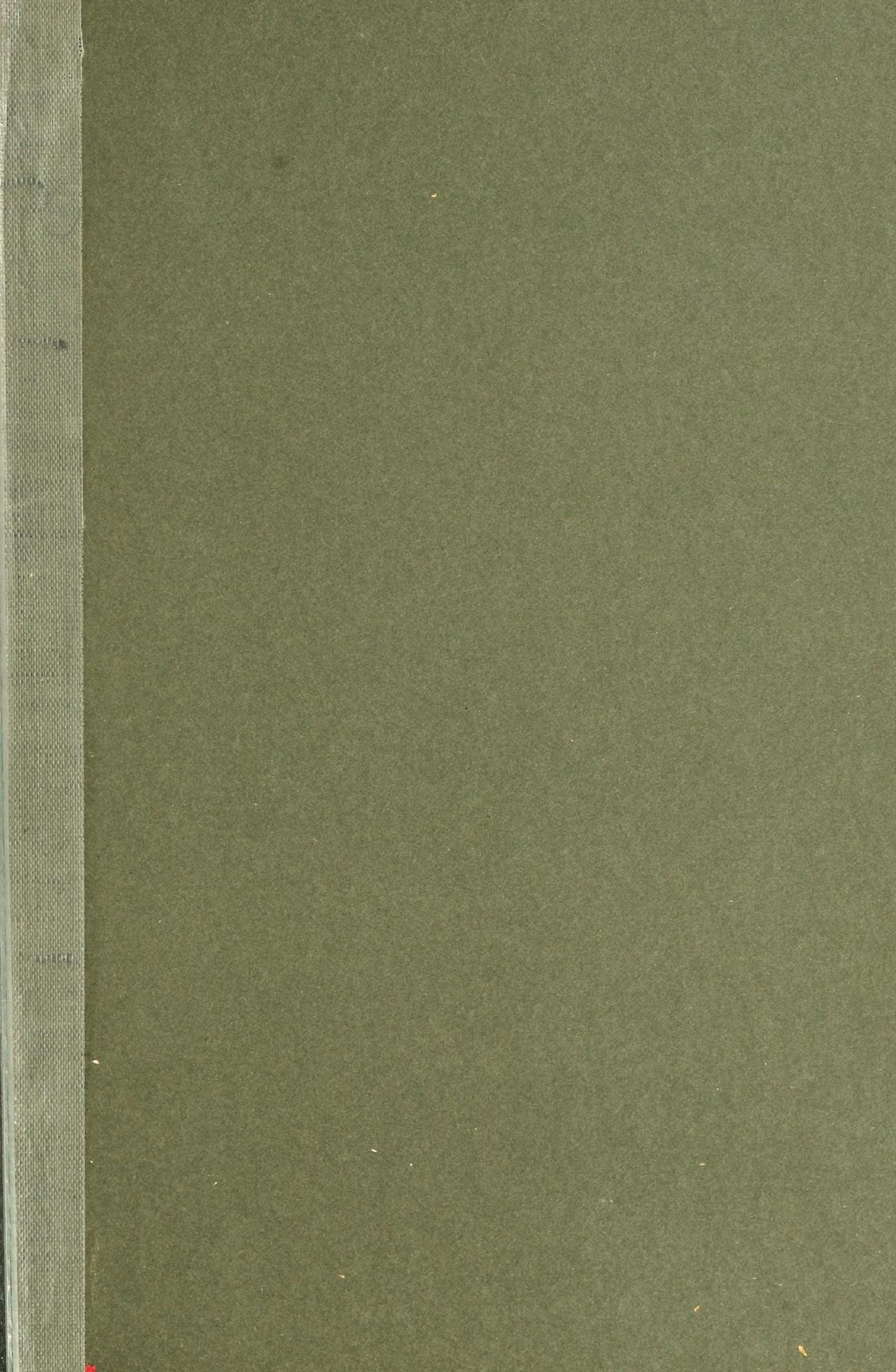




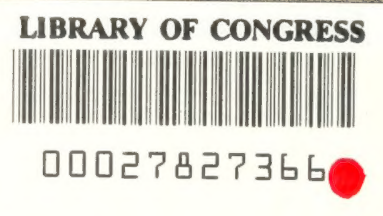

